\title{
PENGARUH THERMAL SHOCK RESISTENCE DAN KOMPOSISI BAHAN REFRAKTORI TERHADAP KEKUATAN IMPACT DAN STRUKTUR MAKRO
}

\author{
April Lianita Sari ${ }^{1}$, Rusiyanto ${ }^{2}$ \\ ${ }^{1,2}$ Pendidikan Teknik Mesin, Universitas Negeri Semarang \\ Email: lianitaapril@gmail.com
}

\begin{abstract}
The purpose of this research is to study the effect of thermal shock and the composition of refractory materials on impact strength and macrostructure. The research methods is experimental method. The independent variables in this research are thermal shock temperatures and the composition of refractory materials (portion of alumina, rice husk ash and kaolin). The dependent variables in this research are impact strength and macrostructure. The data of this research is analyzed using descriptive statistic. The results are presented in tables, charts and images. The result shows that the highest value of average impact strength is $0,009560 \mathrm{~J} / \mathrm{mm}^{2}$ with $300{ }^{\circ} \mathrm{C}$ temperature of thermal shock $(\Delta T)$. The result of the macrostructure is a brittle structure with flat and shiny surface characteristics.
\end{abstract}

Keywords: refractory, composition, thermal shock, impact strength, macrostructure

\begin{abstract}
ABSTRAK
Tujuan dari penelitian ini adalah mengetahui pengaruh thermal shock dan komposisi bahan refraktori terhadap kekuatan impact dan struktur makro. Metode yang digunakan pada penelitian ini merupakan metode eksperimen. Variabel bebas yang digunakan dalam penelitian ini yaitu variasi suhu thermal shock dan variasi komposisi bahan refraktori (alumina, abu sekam padi dan kaolin). variabel terikat yang digunakan dalam penelitian ini yaitu kekuatan impact dan struktur makro. Teknik analisis data yang digunakan adalah analisis deskriptif. data hasil penelitian disajikan dalam bentuk tabel, grafik dan gambar. Hasil penelitian menunjukkan bahwa rata-rata kekuatan impact tertinggi sebesar $0,009560 \mathrm{~J} / \mathrm{mm}^{2}$ diperoleh pada komposisi 5 tanpa perlakuan thermal shock dan terendah sebesar $0,004049 \mathrm{~J} / \mathrm{mm}^{2}$ dengan variasi suhu thermal shock $(\Delta \mathrm{T}) 300{ }^{\circ} \mathrm{C}$ dan hasil foto makro menunjukkan patahan getas dengan ciri-ciri permukaan patahan yang datar dan terlihat mengkilap.
\end{abstract}

Kata kunci: refraktori, komposisi, thermal shock, kekuatan impact, struktur makro

\section{PENDAHULUAN}

Indonesia merupakan salah satu Negara agraris dengan luas wilayah panen padi sebesar 14.116.638 ha dengan hasil produktivitas padi sebanyak 70.846 .465 ton pada tahun 2014 dan mengalami peningkatan pada tahun 2015 sebesar 4.551.376 ton (Badan Pusat Statistik, 2015). Penggilingan padi menghasilkan limbah organik berupa sekam padi yang biasanya dimanfaatkan sebagai media tanam, bahan bakar pembuatan batu bata dan pupuk. Sekam padi yang dibakar mengandung silika amorf

Refraktori mengalami tingkat abrasi yang tinggi karena aliran partikel dengan kecepatan tinggi secara terus-menerus. Oleh reaktif sebesar 87-97\% (Krishanarao dkk, 2001). Silika biasanya digunakan dalam industri kaca, industri refraktori dan keramik, dengan tingginya kandungan silika yang terdapat dalam abu sekam padi maka abu sekam padi dimanfaatkan sebagai bahan baku dalam pembuatan refraktori.

Bahan refraktori merupakan bahan non logam yang tahan terhadap suhu tinggi. Sifatsifat yang harus dimiliki bahan refraktori antara lain memiliki ketahanan terhadap suhu tinggi, memiliki titik lebur yang tinggi dan tahan terhadap tingkat abrasi yang tinggi.

karena itu bahan refraktori harus bersifat abrasif (Sadik dkk, 2014). Salah satu bahan yang bersifat abrasif adalah alumina yang 
terdiri dari aluminium dan oksigen. Alumina memiliki sifat keras dan kuat menahan getaran. Alumina juga mempunyai ketahanan yang baik terhadap suhu tinggi dan bersifat isolator, sehingga alumina dapat dijadikan sebagai bahan paduan dalam pembuatan bahan refraktori (Vlack, 1994: 303-306).

Bahan baku lain yang dapat digunakan dalam pembuatan refraktori adalah lempung kaolin. Kaolin merupakan bahan perekat yang baik sehingga memudahkan proses pembentukan yang memiliki daya hantar listrik dan panas yang rendah sehingga dapat dimanfaatkan sebagai bahan baku pembuatan refraktori. Kaolin merupakan bahan yang memiliki karakteristik keras tetapi getas sehingga dibutuhkan bahan yang memiliki keuletan tinggi dan tetap stabil pada suhu tinggi. Alumina merupakan bahan yang memiliki keuletan tinggi dan tetap stabil pada suhu tinggi sehingga dapat dijadikan sebagai bahan paduan dalam pembuatan refraktori.

Penggunaan refraktori berhubungan dengan suhu tinggi yang berkaitan dengan perubahan suhu. Dalam penelitian ini refraktori diberikan perlakuan thermal shock dan komposisi bahan refraktori terhadap ketahanan impact dan struktur makro.

\section{METODE}

Metode yang digunakan dalam penelitian ini adalah metode penelitian eksperimen, di mana penelitian ini bertujuan untuk mengetahui pengaruh thermal shock resistence dan komposisi bahan refraktori terhadap kekuatan impact dan struktur makro.

Pembuatan spesimen diawali dengan pengayakan abu sekam padi dengan ayakan ukuran mesh 100 kemudian dilakukan proses pencampuran dari ketiga bahan penelitian dengan menggunakan mixer. Variasi komposisi bahan yang dijadikan spesimen uji di antaranya alumina $\left(\mathrm{Al}_{2} \mathrm{O}_{3}\right)$ dengan perbandingan $15 \%, 25 \%, 35 \%, 45 \%, 55 \%$, abu sekam padi $10 \%$ untuk setiap variasi komposisi dan kaolin 75\%, 65\%, 55\%, 45\%, 35\%.
Selanjutnya bahan penelitian dicampur dengan alkohol sebanyak 30\%, di mna bahan yang sudah tercampur kemudian dimasukkan dalam cetakan kemudian dikompaksi menggunakan mesin press dengan kekuatan $80 \mathrm{~kg} / \mathrm{cm}^{2}$.

Spesimen yang sudah dicetak selanjutnya didiamkan dalam suhu ruangan selama 3 hari dan setelah itu disintering pada suhu $1200{ }^{\circ} \mathrm{C}$ dengan laju pemanasan 5 ${ }^{\circ} \mathrm{C} /$ menit dengan holding time 2 jam. Kemudian spesimen uji diberikan perlakuan thermal shock $(\Delta \mathrm{T}) 0^{\circ} \mathrm{C}, 100{ }^{\circ} \mathrm{C}, 200{ }^{\circ} \mathrm{C}, 300$ ${ }^{\circ} \mathrm{C}$. Spesimen yang telah diberikan perlakuan dilakukan pengujian impact dan struktur makro. Pengujian impact dilakukan untuk mengetahui ketahanan impact spesimen uji setelah diberikan perlakuan. Struktur makro digunakan untuk mengetahui bentuk patahan yang terjadi setelah dilakukan uji impact.

\section{HASIL DAN PEMBAHASAN}

Pengujian impact dilakukan untuk mengetahui ketahanan suatu material terhadap beban kejut yang datang secara cepat dan tibatiba.

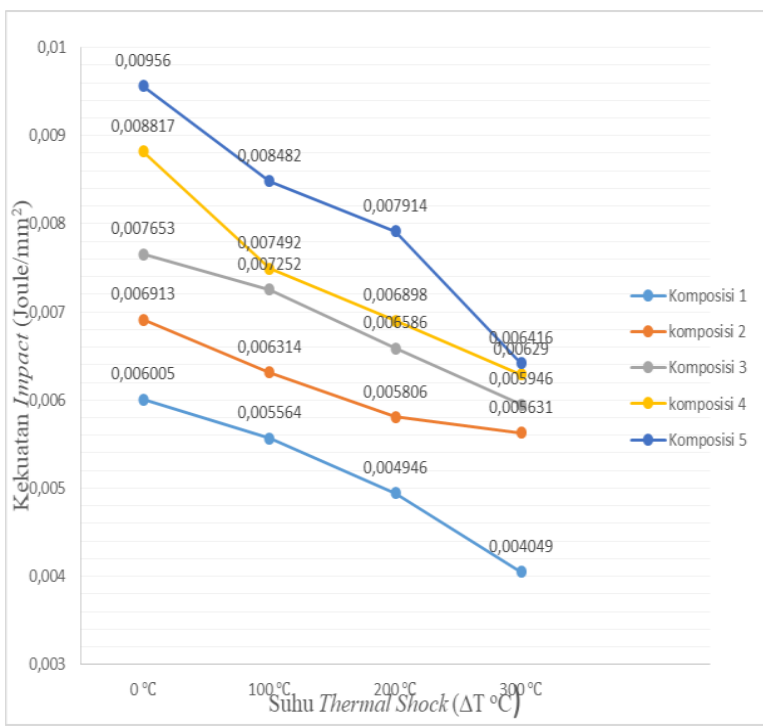

Gambar 1. Grafik Perhitungan Uji Impact Komposisi 1-5

Hasil rata-rata perhitungan uji impact pada Gambar 1 menunjukkan bahwa pada setiap variasi suhu thermal shock dan variasi 
komposisi spesimen uji memiliki kekuatan impact yang berbeda, sehingga dapat dikatakan bahwa suhu thermal shock dan komposisi bahan refraktori memiliki pengaruh terhadap kekuatan impact spesimen uji. Rata-rata kekuatan impact tertinggi diperoleh pada variasi komposisi 5 tanpa perlakuan thermal shock $(\Delta \mathrm{T}) 0{ }^{\circ} \mathrm{C}$ sebesar $0,009560 \mathrm{~J} / \mathrm{mm}^{2}$. Hasil perhitungan uji impact menunjukkan bahwa terdapat penurunan kekuatan impact spesimen uji pada setiap kenaikan variasi suhu thermal shock dari semua variasi komposisi bahan refraktori.

\section{Struktur Makro}

Pengamatan struktur makro dilakukan untuk mengetahui bentuk patahan yang terjadi pada spesimen setelah dilakukan uji impact. Hasil pengamatan foto marko dapat dilihat pada gambar berikut.

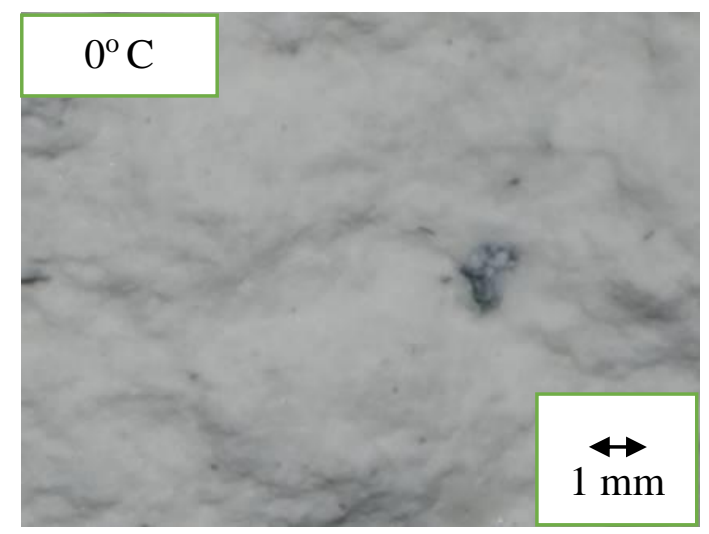

Gambar 2. Foto Makro Komposisi $1 \Delta \mathrm{T} 0{ }^{\circ} \mathrm{C}$

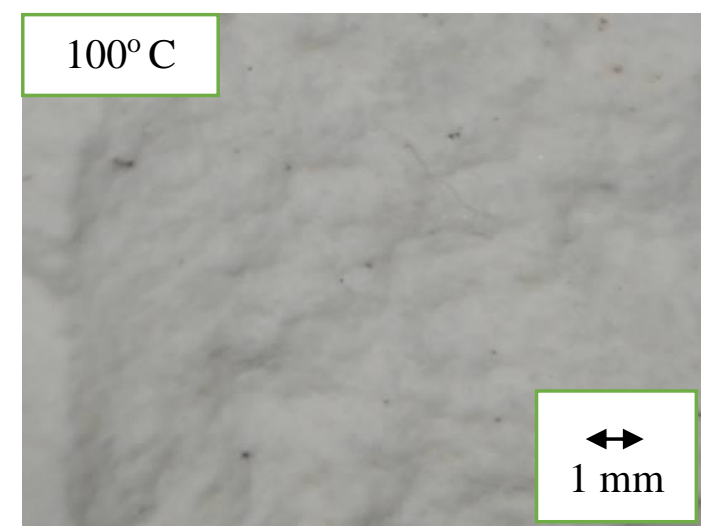

Gambar 3. Foto Makro Komposisi $1 \Delta \mathrm{T}$ $100{ }^{\circ} \mathrm{C}$

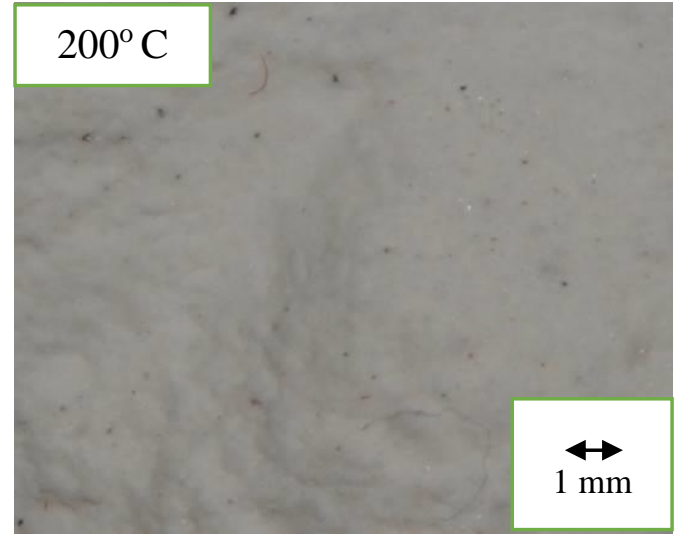

Gambar 4. Foto Makro Komposisi $1 \Delta \mathrm{T}$ $200{ }^{\circ} \mathrm{C}$

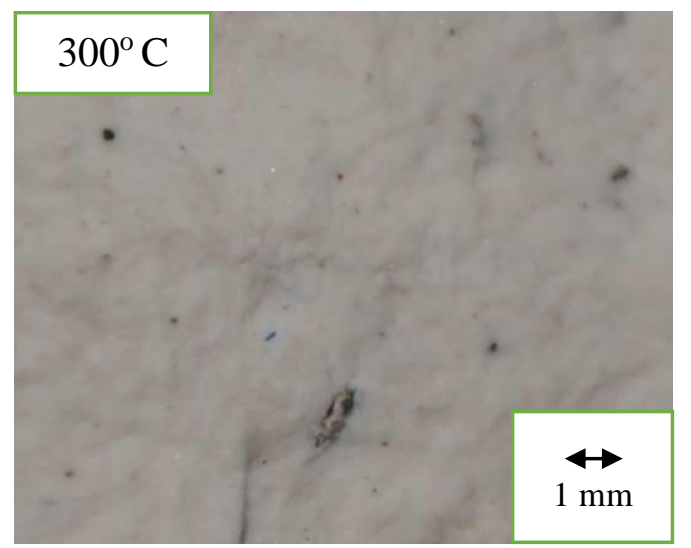

Gambar 5. Foto Makro Komposisi $1 \Delta \mathrm{T} 300^{\circ} \mathrm{C}$
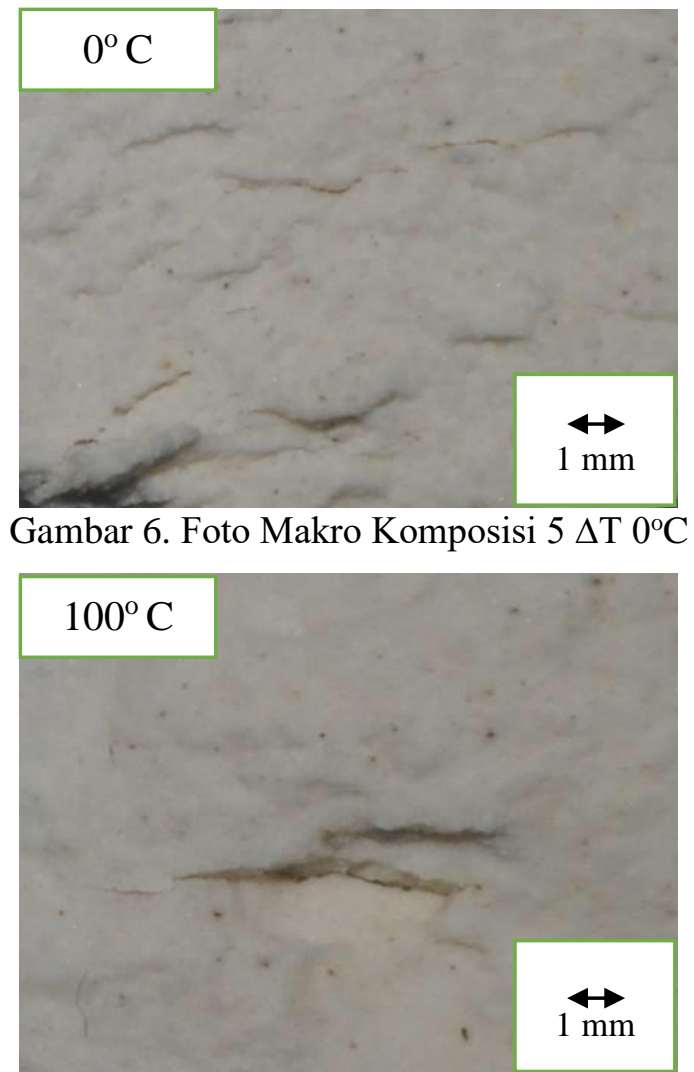

Gambar 7. Foto Makro Komposisi $5 \Delta \mathrm{T} 100^{\circ} \mathrm{C}$ 


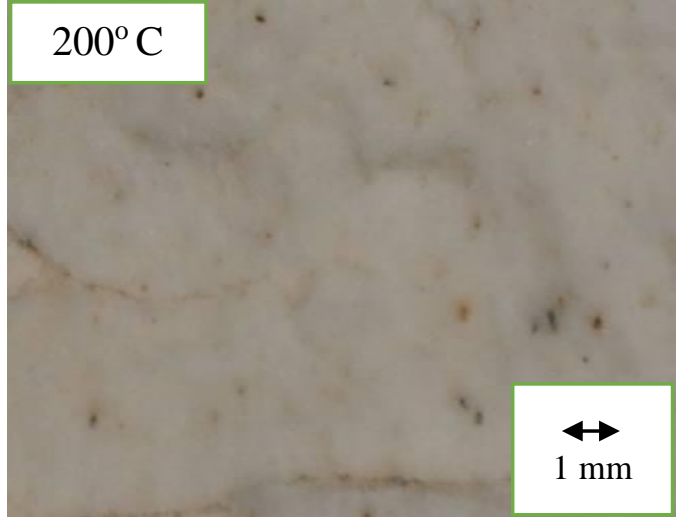

Gambar 8. Foto Makro Komposisi $5 \Delta \mathrm{T} 200^{\circ} \mathrm{C}$

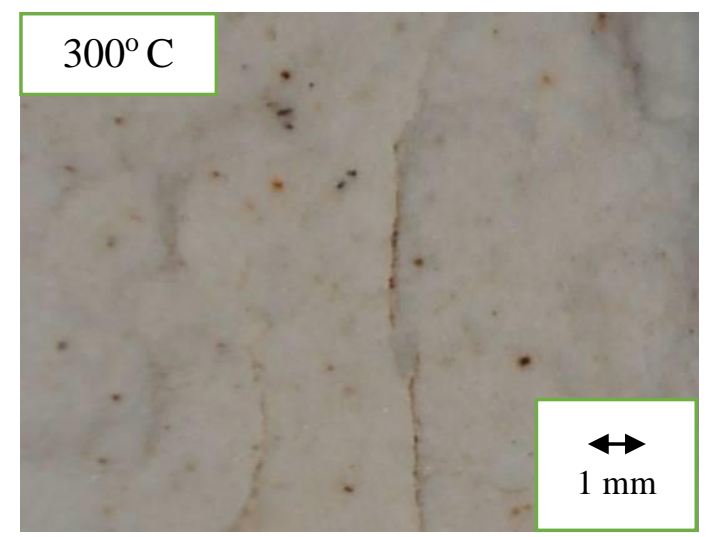

Gambar 9. Foto Makro Komposisi $9 \Delta \mathrm{T} 300^{\circ} \mathrm{C}$

Berdasarkan pengambilan foto makro, patahan spesimen uji impact berbentuk patahan granular atau patahan getas yang ditandai dengan patahan datar yang memantulkan cahaya tinggi dan terlihat mengkilap yang disebabkan oleh mekanisme pembelahan pada butir-butir keramik yang getas.

Perlakuan thermal shock spesimen akan menerima penurunan suhu secara drastis. Proses ini terjadi ketika perambatan suhu pada spesimen mengalami pemuaian yang tidak seragam diasumsikan sebagai tegangan, sehingga perlakuan thermal shock ini akan menyebabkan penurunan kekuatan impact pada spesimen karena pendinginan yang dilakukan secara cepat. Pada penelitian ini, kekuatan impact yang didapatkan menurun seiring dengan peningkatan suhu pada perlakuan thermal shock, seperti penelitian yang dilakukan oleh Bayuseno (2009) dengan menggunakan variasi suhu $300{ }^{\circ} \mathrm{C}, 400{ }^{\circ} \mathrm{C}$ dan $500{ }^{\circ} \mathrm{C}$ juga menunjukkan bahwa setiap suhu thermal shock dinaikkan $100{ }^{\circ} \mathrm{C}$ nilai kekuatan mekanik mengalami penurunan sebesar 37,5\%. Penurunan tersebut terjadi karena koefisien termal dan modulus elastisitas yang dimiliki keramik tinggi sehingga mengakibatkan tegangan termal yang menyebabkan terjadinya retakan yang merambat cepat karena perbedaan suhu yang tinggi. Karso dkk (2012) memaparkan bahwa kekuatan impact mengalami penurunan sebesar $74,33 \%$ seiring dengan peningkatan suhu thermal shock dari 60-110 ${ }^{\circ} \mathrm{C}$ di mana hal ini disebabkan oleh ikatan material dan HDPE rusak akibat adanya perubahan suhu yang tinggi.

Menurut penelitian yang dilakukan oleh Sari dkk (2017) semakin tinggi variasi suhu thermal shock menyebabkan nilai kekuatan impact kowi pelebur mengalami penurunan, maka ketangguhan dan kekerasan yang dimiliki kowi pelebur menjadi semakin rendah. Jin \& Yhuezong (2014) melakukan penelitian pada keramik dengan komposisi bahan $\mathrm{Al}_{2} \mathrm{O}_{3} / \mathrm{Si}_{3} \mathrm{~N}_{4}$ diberi perlakuan thermal shock dengan suhu $100-500{ }^{\circ} \mathrm{C}$ di mana menyatakan bahwa kekuatan mekanik spesimen mengalami penurunan. Tegangan sisa yang diperoleh mengalami penurunan signifikan pada suhu thermal shock $(\Delta \mathrm{T}) 500{ }^{\circ} \mathrm{C}$. Kenaikan suhu thermal shock memiliki pengaruh terhadap kekuatan impact yang dimiliki oleh suatu material, pada penelitian ini menggunakan variasi suhu $0-300{ }^{\circ} \mathrm{C}$ terlihat penurunan secara drastis pada saat diberikan variasi suhu thermal shock. Kekuatan impact terendah diperoleh pada suhu thermal shock $(\Delta \mathrm{T}) 300{ }^{\circ} \mathrm{C}$ pada setiap variasi komposisi.

Pada setiap variasi komposisi memiliki nilai kekuatan impact yang berbeda, hal ini menunjukkan bahwa komposisi spesimen berpengaruh terhadap sifat mekanis dari spesimen uji. Berdasarkan hasil pengujian impact, seiring dengan penambahan alumina pada komposisi spesimen kekuatan impact yang diperoleh semakin meningkat. Terjadi peningkatan kekuatan impact pada setiap penambahan presentase alumina pada komposisi bahan. Kekuatan impact tertinggi diperoleh pada variasi komposisi $5(25 \%, 10 \%$, 
$65 \%$ ) dengan hasil pada $\Delta \mathrm{T} 0{ }^{\circ} \mathrm{C}$ sebesar $0,009560 \mathrm{~J} / \mathrm{mm}^{2}, \Delta \mathrm{T} 100{ }^{\circ} \mathrm{C}$ sebesar 0,008482 $\mathrm{J} / \mathrm{mm}^{2}, \Delta \mathrm{T} 200{ }^{\circ} \mathrm{C}$ sebesar $0,007914 \mathrm{~J} / \mathrm{mm}^{2}$ dan $\Delta \mathrm{T} 300{ }^{\circ} \mathrm{C}$ sebesar $0,006416 \mathrm{~J} / \mathrm{mm}^{2}$. Hal ini membuktikan bahwa penambahan presentase alumina dapat meningkatkan kekuatan impact spesimen.

Penelitian yang dilakukan oleh Hamzah (2017) memberikan hasil bahwa kekuatan impact pada fire brick semakin meningkat seiring dengan bertambahnya fraksi berat alumina dan suhu sintering. Peningkatan maksimum terjadi pada presentase alumina $60 \%$ pada suhu sintering $1300{ }^{\circ} \mathrm{C}$. Hal ini disebabkan oleh tingginya suhu sintering yang membuat partikel serbuk menjadi terikat lebih baik dan penambahan fraksi berat alumina yang dapat meningkatkan kekuatan dan ketangguhan fire brick. Menurut penelitian yang dilakukan oleh Sidabutar (2017) kekuatan mekanik mengalami peningkatan seiring dengan penambahan alumina dan kenaikan suhu sintering. Kekuatan mekanik terbaik didapatkan pada penambahan alumina sebanyak $10 \%$ dan suhu sintering $1200{ }^{\circ} \mathrm{C}$. Hasil ini sesuai dengan penelitian yang dilakukan oleh Muhammad Sadat Hamzah \& Alimuddin Sam (2013) di mana peningkatan fraksi berat alumina akan meningkatkan kekuatan mekanik komposit clay untuk aplikasi fire brick, kekuatan mekanik dalam penelitian tersebut adalah kekuatan bending.

Patahan spesimen dari hasil uji impact dilihat mekanisme perpatahannya. Untuk mengamati bentuk patahan dari masing-masing variasi suhu thermal shock $(\Delta \mathrm{T})$ dan variasi komposisi dilakukan foto makro pada permukaan patahan spesimen. berdasarkan hasil foto makro, jenis perpatahan yang dialami oleh spesimen adalah perpatahan getas yang ditandai dengan permukaan patahan yang datar dan pantulan cahaya yang mengkilap. Pada variasi komposisi 5 terlihat lebih padat dibandingkan dengan variasi komposisi yang lain, hal ini dikarenakan alumina memiliki titik lebur yang lebih tinggi sehingga dapat mengisi ruang-ruang kosong pada spesimen, sehingga spesimen terlihat lebih padat dan spesimen berkurang. Hal ini membuktikan bahwa komposisi bahan refraktori berpengaruh terhadap struktur makro spesimen uji, sesuai dengan penelitian yang dilakukan oleh Suarsana (2015) yang menyatakan bahwa penambahan berat alumina dapat menurunkan tingkat porositas dan meningkatkan kepadatan spesimen uji.

Kenaikan suhu thermal shock $(\Delta \mathrm{T})$ memiliki pengaruh terhadap struktur makro spesimen. Pada variasi suhu thermal shock $(\Delta \mathrm{T})$ 0-300 ${ }^{\circ} \mathrm{C}$ terdapat perbedaan warna pada spesimen, semakin bertambahnya suhu thermal shock $(\Delta \mathrm{T})$ permukaan patahan spesimen terlihat berwarna lebih gelap. Hasil ini sesuai dengan penelitian yang dilakukan oleh Sari dkk (2017) yang menunjukkan bahwa terdapat perbedaan distribusi warna pada patahan spesimen yang diberi perlakuan thermal shock, semakin tinggi suhu thermal shock $(\Delta \mathrm{T})$ terlihat bahwa struktur makro dari spesimen terlihat dominan berwarna gelap.

\section{SIMPULAN}

Kesimpulan dari penelitian ini adalah sebagai berikut. (1) Pengaruh thermal shock dan komposisi bahan refraktori terhadap kekuatan uji impact dapat disimpulkan bahwa semakin tinggi suhu thermal shock $(\Delta \mathrm{T})$ kekuatan impact yang diperoleh semakin menurun. Setiap variasi komposisi bahan memiliki kekuatan impact yang berbeda-beda, penambahan presentase berat alumina dapat meningkatkan kekuatan impact pada spesimen uji. (2) Pengaruh thermal shock dan komposisi bahan refraktori terhadap struktur makro dapat disimpulkan bahwa patahan spesimen memiliki permukaan yang datar dan memantulkan cahaya yang mengkilap. Semakin tinggi suhu thermal shock, pada patahan spesimen terlihat memiliki warna yang semakin gelap. 


\section{DAFTAR RUJUKAN}

Badan Pusat Statistik (BPS). 2015. Diakses dari http://www.bps.go.id/ pada tanggal 15 Desember 2018 pukul 13:49.

Bayuseno, A.P. 2009. Pengembangan dan Karakterisasi Material Keramik Untuk Dinding Bata Tahan Api Tungku Hoffman KI. Jurnal Rotasi 11(4): 510.

Hamzah, M.S. 2017. Kekuatan Impak Komposit Clay dan Alumina untuk Aplikasi Fire Brick. Jurnal Mekanikal 8(2): 716-720.

Jin Z \& Yuezhong F. 2014. Thermal Shock Resistence Behavior of a Functionally Graded Ceramic: Effects of Finite Cooling Rate. The Chinese Society of Theoritical and Applied Mechanics 4(4): 1-5.

Karso, T., Wijang, W.R., Heru, S. 2012. Pengaruh Variasi Suhu Siklus Termal terhadap Karakteristik Mekanik Komposit HDPE-Sampah Organik. Jurnal Mekanika 11(1): 9-13.

Krishnarao, R.V., J. Subrahmanyam, T. Jagadish Kumar. 2001. Studies on the Formation of Black Particles in Rice Husk Silica Ash. Journal of the European Ceramic Society 21: 99-104.

Muhammad Sadat Hamzah \& Alimuddin Sam. 2013. Kekuatan Bending Komposit
Clay Diperkuat dengan Alumina untuk Aplikasi Fire Brick. Jurnal Mekanikal 4(2): 403-409.

Sadik, C., Iz-Eddine, E. A., Abderrahman, A. 2014. Recent Advance in SilicaAlumina Refractory: A review. Journal of Asian Ceramic Societies 76(14): 1-14.

Sari, D.R., Rusiyanto, Rahmat, D.W., Pramono. 2017. Pengaruh Thermal Shock Resistence terhadap Makro Struktur dan Ketahanan Impact Kowi Pelebur (Crusible) Berbahan Komposit Abu Sekam Padi/ Grafit/ Kaolin. Jurnal Kompetensi Teknik 9(1): 53-59.

Sidabutar, T.E. 2017. Pembuatan dan Karakterisasi Keramik Magnesium Alumina Silika dari Abu Vulkanik Gunung Sinabung. Jurnal Teknik Mesin (JTM) 6(1): 28-35.

Suarsana, K. 2015. Efek Temperatur Sintering pada Penambahan Penguat $\mathrm{SiCw}$ dan $\mathrm{Al}_{2} \mathrm{O}_{3}$ Partikel terhadap Karakteristik Aluminium Matrik Komposit. Artikel disajikan pada Seminar Nasional Teknologi 2015. Institut Teknologi Nasional Malang. 17 Januari 2015.

Vlack, L.H.V. 1985. Elements of Materials Science and Engineering. Edisi kelima. Addison-Wesley Publishing Company. Michigan. Djaprie, S. 1994. Ilmu dan Teknologi Bahan. Edisi kelima. Jakarta: Erlangga. 